\title{
Analiza mikrofacjalna dolomitu głównego (Ca2) we wschodniej części wielkopolskiej platformy węglanowej \\ Ewelina Krzyżak ${ }^{1}$
}

\begin{abstract}
Microfacies analysis of the Main Dolomite (Ca2) in the eastern part of the Wielkopolska Carbonate Platform (W Poland). Prz. Geol., 67: 172-175; doi: 10.7306/2019.12

A b s tr a c t. Investigation of the Permian Basin in the western part of the Polish Lowland was initiated in 1961 when the Rybaki field was discovered - the first one outside the Carpathians in Poland. The Main Dolomite (Ca2) in the eastern part of the Wielkopolska Platform, located in western Poland, is characterized by a significant variety of microfacies, hence this research is aimed at better interpretation and understanding of depositional environments of current reservoir rocks as well as possibility of identification of facies distribution within the investigated carbonate platform. A detailed microfacies analysis of the Main Dolomite was conducted, which was supported by core logging. The author interpreted depositional environments and generated a $3 D$ model of the top of the Main Dolomite using seismic reflection data. An attempt to correlate microfacies between the analyzed wells was also performed. Integrated analyses of thin sections and drill cores from 4 wells allowed me to interpret the depositional environments of the Main Dolomite. The generated 3D model of the top of the Main Dolomite provided a better insight into subsurface tectonics, paleogeography of the analyzed area and a better understanding of depositional lithofacies environments.
\end{abstract}

Keywords: Permian Basin, Zechstein Main Dolomite (Ca2), carbonate platform, microfacies analysis

\footnotetext{
${ }^{1}$ Państwowy Instytut Geologiczny - Państwowy Instytut Badawczy, ul. Rakowiecka 4, 00-975 Warszawa; ewelina.krzyzak@pgi.gov.pl
} 
Badania utworów permskich w zachodniej części Niżu Polskiego rozpoczęły się w 1961 r., kiedy odkryto pierwsze złoże ropo-gazonośne na północ od Karpat - złoże Rybaki (Dyjaczyński i in., 2006). Dolomit główny w rejonie wschodniej części wielkopolskiej platformy węglanowej (zachodnia Polska) charakteryzuje się bardzo dużą zmiennością mikrofacjalną. W związku z tym wykonanie jego szczegółowej analizy mikrofacjalnej jest niezbędne do lepszego poznania warunków sedymentacji w czasie depozycji obecnych skał ropo- i gazonośnych, możliwości określenia stref sedymentacji w obrębie platformy węglanowej, a także ze względu na występowanie bezpośredniego związku między niejednorodnością wykształcenia dolomitu głównego, jego diagenezą i w efekcie właściwościami zbiornikowymi.

Celem pracy było wykonanie analiz sedymentologicznych w otworach wiertniczych (Grotów-1, Sieraków-1, Kaczlin-1 oraz Gnuszyn-1), które zostały szczegółowo wyselekcjonowane, aby uchwycić zmienność mikrofacjalną w różnych środowiskach depozycyjnych dolomitu głównego. Pod uwagę była brana również dostępność materiałów geologicznych, w tym rdzeni wiertniczych i szlifów petrograficznych. Wykonane analizy zostały wzbogacone o model 3D morfologii stropu dolomitu.

\section{BUDOWA GEOLOGICZNA}

Utwory dolomitu głównego w polskiej części basenu cechsztyńskiego są reprezentowane przez dolomity i wapienie zarówno twarde i zbite, jak i kruche oraz porowate. Występowanie dolomitów jest związane głównie ze środowiskiem platformy węglanowej (litofacja dolomitowa), natomiast wapieni - ze strefą skłonu platformy i równi basenowej (litofacja wapienna). Obok utworów węglanowych dość często występują siarczany. Są one obecne głównie w górnych i dolnych częściach profilu, czyli przy kontakcie z anhydrytem (Czekański i in., 2010; Dyjaczyński i in., 2009).

\section{METODYKA PRAC}

Pierwszy etap prac polegał na opisie makroskopowym, podczas którego przebadano 151,5 m rdzenia wiertniczego dolomitu głównego. Następnie dokonano szczegółowego opisu 183 płytek cienkich przy użyciu mikroskopu polaryzacyjnego Leica M205C, wzbogacając go o dokumentację fotograficzną wybranych próbek. Ostatnim etapem było wykonanie modelu 3D morfologii stropu dolomitu głównego na podstawie informacji geologicznej ze zdjęcia sejsmicznego 3D Międzychód-Sieraków wykonanego przez Geofizykę Toruń S.A.

\section{WYNIKI}

W wyniku przeprowadzonych prac analitycznych scharakteryzowano skały w poszczególnych otworach wiertniczych, dokonano ich rejestracji fotograficznej w płytkach cienkich (ryc. 1) oraz wykonano model morfologii stropu dolomitu głównego (Ca2) (ryc. 2).

Poniżej przedstawiono wyniki przeprowadzonych analiz z podziałem na poszczególne otwory wiertnicze.

Grotów-1. Miąższość utworów dolomitu głównego wynosi 33,4 m. Jest on wykształcony w przeważającej części $\mathrm{w}$ postaci ciemnoszarego dolomitu pelitycznego $(25,6 \mathrm{~m}-$ 76\%). Obecność laminitów algowych (bindston), które są dominującą facją w opisywanym otworze, świadczy prawdopodobnie o depozycji w środowisku o niskiej energii (laguna). Dodatkowo rozpoznano grainstony onkoidowo-intraklastowe, które wskazują na środowisko o wysokiej energii - depozycję utworów Ca2 w środowisku na pograniczu bariery zewnętrznej i niskoenergetycznej równi platformowej.

Sieraków-1. Dolomit główny o miąższości 57,0 m jest wykształcony jako dolomity pelityczne (mudston $\sim 73,7 \%$ ) i dolomity ziarniste (grainston $\sim 26,3 \%$ ). W płytkach cienkich dominują mikrofacje grainstonów onkoidowo-intraklastowych. Świadczą one o wysokiej energii środowiska, które zinterpretowano jako środowisko bariery zewnętrznej.

Kaczlin-1. Miąższość utworów dolomitu głównego wynosi 33,0 m. Makroskopowo rozpoznano tutaj dolomity pelityczne - mudstony ( $\sim 58 \%$ badanego rdzenia), oraz dolomity ziarniste $(\sim 42 \%)$, natomiast analiza płytek cienkich wykazała bardzo duże zróżnicowanie mikrofacjalne, świadczące prawdopodobnie o redepozycji materiału pocho-
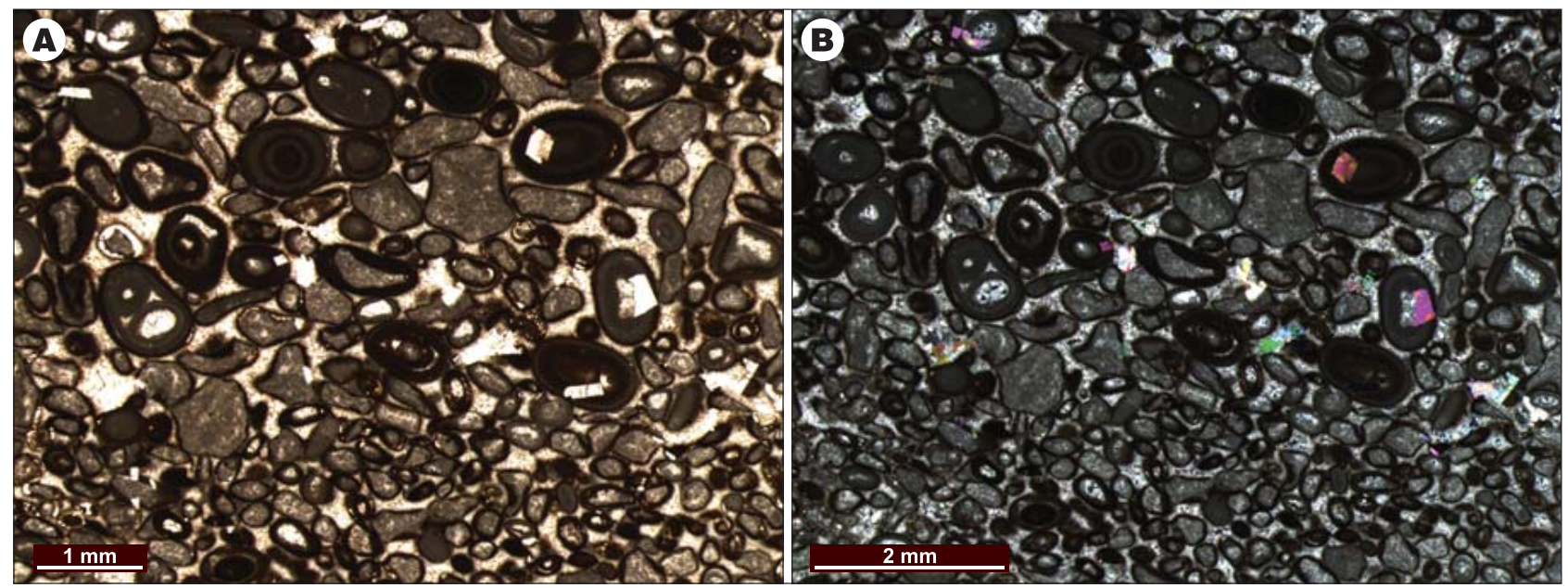

Ryc. 1. Grainston, onkoidy proste i złożone; miejscami widoczny cement anhydrytowy i impregnacje anhydrytowe. A - zdjęcie wykonane przy $1 \mathrm{~N}, \mathbf{B}$ - przy skrzyżowanych nikolach

Fig. 1. Grainstone, simple and composite oncoids; in places anhydrite cement and anhydrite impregnations are visible. A-photo taken at plane-polarized light, $\mathbf{B}$ - at cross-polarized light 


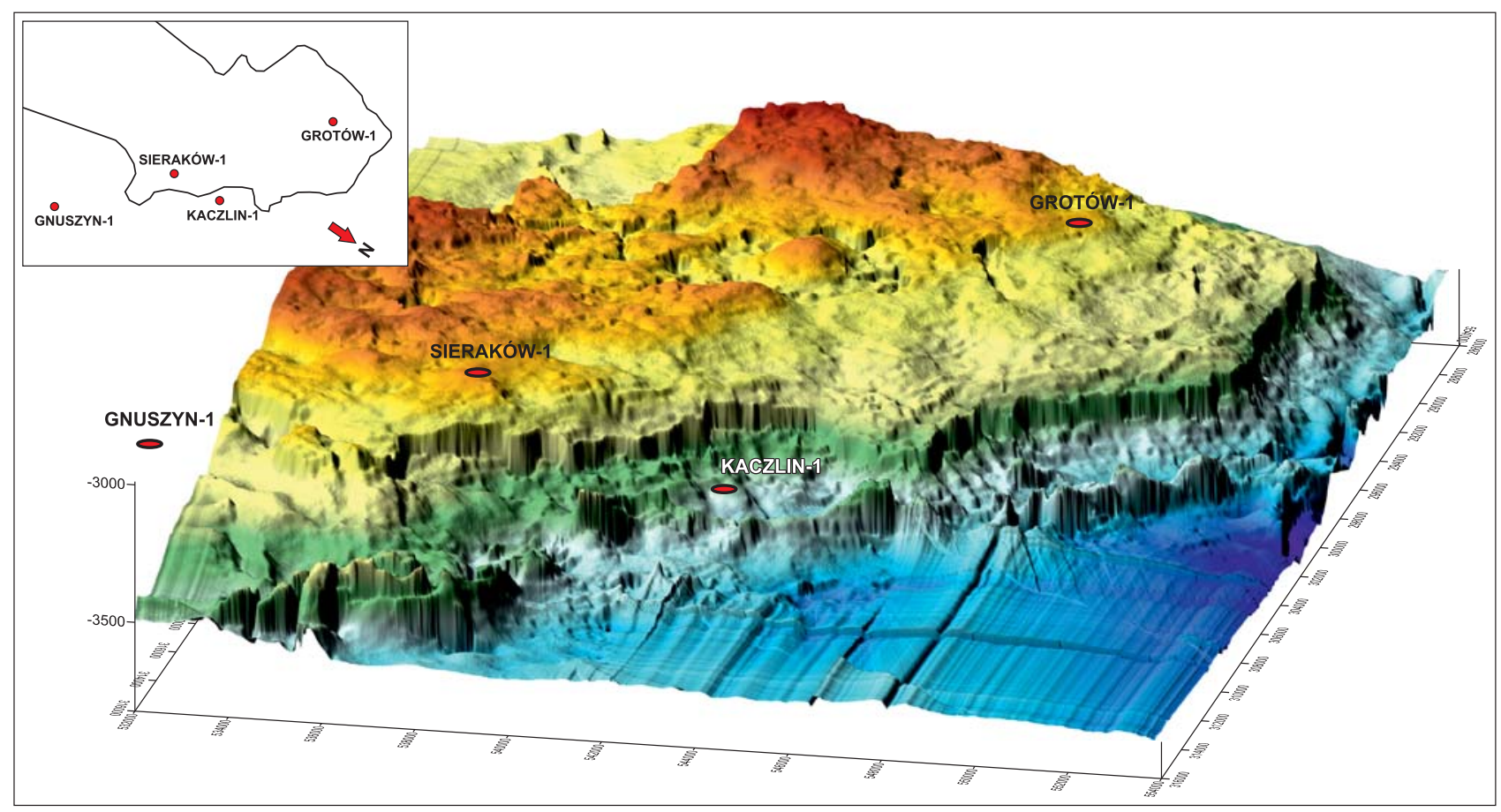

Ryc. 2. Model morfologii stropu dolomitu głównego (Ca2) na podstawie zdjęcia sejsmicznego 3D Międzychód-Sieraków (Krzyżak, 2014) Fig. 2. Top surface morphology model of the Main Dolomite based on the Międzychód-Sieraków 3D seismic survey (Krzyżak, 2014)

dzącego z niszczenia elementów bariery. Najpowszechniej występują grainstony oraz mudstony, zinterpretowane jako osady z pogranicza skłonu bariery zewnętrznej i równi basenowej.

Gnuszyn-1. Miąższość dolomitu głównego wynosi 8,5 m. Rozpoznano tutaj wyłącznie wapienie pelityczne mudstony ( $\sim 99 \%)$, z niewielką domieszką wapieni drobnokrystalicznych $(\sim 1 \%)$. W płytkach cienkich dominuja mikrofacje wapieni krystalicznych, a pobocznie występuja mudstony oraz wackstony, które zinterpretowano jako osady środowisk równi basenowej.

Podstawą przedstawionej analizy jest model facji Wilsona (za Flügel, 2004) oraz interpretacja środowisk sedymentacji dolomitu głównego w NW części Polski (Protas, 1979).

\section{WNIOSKI}

Na podstawie analizy 183 płytek cienkich ze wschodniej części wielkopolskiej platformy węglanowej wydzielono sześć mikrofacji: mudston, wackston, packston, grainston, laminit algowy (bindston) oraz wapień krystaliczny. Przy tej okazji dokonano również opisu makroskopowego $151,5 \mathrm{~m}$ rdzenia wiertniczego. Badania te pozwoliły zinterpretować środowiska sedymentacji utworów węglanowych. Dodatkowo, na podstawie danych sejsmicznych stworzono trójwymiarowy model morfologii stropu dolomitu, który potwierdził wyniki analizy sedymentologicznej dolomitu głównego $\mathrm{w}$ analizowanych otworach wiertniczych.

Integracja wyników analiz petrograficznych i obserwacji makroskopowych, wykonanych na czterech rdzeniach wiertniczych, pozwoliła zidentyfikować następujące środowiska sedymentacji utworów dolomitu głównego:

- Grotów-1 - strefa przejściowa między barierą zewnętrzną i niskoenergetyczną równią platformową,
- Sieraków-1 - bariera zewnętrzna,

- Kaczlin-1 - strefa przejściowa między skłonem bariery zewnętrznej a równią basenową,

- Gnuszyn-1 - głębsza część równi basenowej.

Wykonanie trójwymiarowego modelu stropu morfologii dolomitu głównego (ryc. 2) umożliwiło dokładniejsze poznanie budowy tektonicznej oraz paleogeografii badanego terenu oraz zrekonstruowanie warunków sedymentacji litofacji nawiercanych utworów.

$\mathrm{Na}$ obecnym etapie rozpoznawania utworów węglanowych dolomitu głównego do precyzyjnego typowania miejsc akumulacji ropy naftowej i gazu ziemnego nie wystarcza znajomość ogólnej paleogeografii oraz zmian facjalnych tego poziomu. Niezbędne okazują się lokalne badania mikrofacji utworów węglanowych prowadzone na szerszą skalę, co umożliwia lepsze poznanie środowisk sedymentacji skał węglanowych oraz trafniejsze typowanie potencjalnych litologicznych pułapek węglowodorów. Doskonałym uzupełnieniem prowadzonych prac było by wykonanie analiz składu chemicznego materiałów ilastych, występujących w dolomicie głównym oraz badań związanych $\mathrm{z}$ poznaniem procesów diagenetycznych, silnie zachodzących w utworach Ca2 i mogących mieć kluczowy wpływ na właściwości zbiornikowe skały.

W artykule przedstawiono wyniki badań uzyskane w ramach realizacji pracy magisterskiej autorki, wykonanej na Uniwersytecie im. Adama Mickiewicza w Poznaniu. Materiał do badań uzyskano dzięki uprzejmości Polskiego Górnictwa Naftowego i Gazownictwa S.A. Ponadto korzystano z danych sejsmicznych, które zostały udostępnione przez Geofizykę Toruń S.A. Autorka składa serdeczne podziękowania PGNiG S.A. za udostęnienie materiałów niezbędnych do realizacji pracy oraz Panu Piotrowi Godlewskiemu, pracownikowi Geofizyki Torun S.A. za pomoc w stworzeniu modelu 3D morfologii stropu dolomitu głównego. Szczególne podziękowania składam moim promotorom dr hab. Joannie Rotnickiej oraz dr. Aleksandrowi Protasowi. 


\section{LITERATURA}

CZEKAŃSKI E., KWOLEK K., MIKOŁAJEWSKI Z. 2010 - Złoża węglowodorów w utworach cechsztyńskiego dolomitu głównego (Ca2) na bloku Gorzowa. Prz. Geol., 58 (8): 695-703.

DYJACZYŃSKI K., MAMCZUR S., DZIADKIEWICZ M. 2006 - Od

Rybaków do L-M-G 45 lat wydobycia ropy naftowej na Niżu Polskim. [W:] 50 lat poszukiwań ropy naftowej i gazu ziemnego w północnozachodniej Polsce. Piła: 57-76.

DYJACZYŃSKI K., KWOLEK K., MIKOLAJEWSKI Z., PERYT T.M. SŁOWAKIEWICZ M. 2009 - Microplatforms of the Main Dolomite $(\mathrm{Ca} 2)$ in western Poland in the aspect of hydrocarbon prospection. 6
Annual Conference of SEPM-CES SEDIMENT, 24-25 June 2009, Kraków: 14-15.

FLÜGEL E. 2004 - Microfacies of Carbonate Rocks. [W:] Discussion and Use of Standard Facies Zones, Wyd. Springer, Berlin.

KRZYŻAK E. 2014 - Analiza mikrofacjalna dolomitu głównego (Ca2) we wschodniej części wielkopolskiej platformy węglanowej. Praca magisterska. Mat. niepub. dostępne w czytelni Instytutu Geologii w Poznaniu.

PROTAS A. 1979 - Zróżnicowanie mikrofacjalne dolomitu głównego w NW części Synklinorium Szczecińskiego i Antyklinorium Pomorskiego, Piła-Wrocław. 